\title{
Failing Institutions Are at the Core of the U.S. Financial Crisis
}

\author{
Dr. Yochanan Shachmurove \\ Department of Economics and Business \\ The City College of the City University of New York, and \\ The Ph.D. Program in Economics, The Graduate School and \\ University Center of The City University of New York
}

\section{ABSTRACT}

October 17, 2012

This paper uses the structure of institutional economics to provide an explanation of the recent U.S. financial crisis. Institutional theory suggests that a county's political, legal, social, and cultural institutions determine and characterize its economy. An institutional perspective of financial crises therefore incorporates unquantifiable aspects of the real world. Different institutions interacted to ignite and fuel the global crisis. A thorough understanding of all of the legal, political, and cultural institution that encompass a society, as well as their role in the market, is needed to explain and avoid the reoccurrences of financial crises.

JEL Classification: G, O1, B52

Key Words: Institutional Economics; Financial Crisis; Law and Economics; Interdependence; Behavioral Economics; Behavioral Finance; Hume; Veblen; Coase

I would like to acknowledge the help of Veselin Draskovic from the University of Montenegro. In addition, I would like to thank Emanuel, Amir and Tomer Shachmurove for insightful discussions on the topics presented in this paper. I have benefited from many years of counsel and guidance of Cynthia Cronin-Kardon of the Wharton School of the University of Pennsylvania, and the capable research assistance of Jenny Xia from the University of Pennsylvania.

The research leading to this paper has been partially supported by the Shwager Fund at The City College of The City University of New York. All remaining errors are mine.

Please address all correspondence to: Professor Yochanan Shachmurove, Department of Economics and Business, The City College of The City University of New York, 160 Convent Avenue, New York, New York 10031. Email Address: yshachmurove@ccny.cuny.edu

Please address all correspondence during the summer to: Professor Yochanan Shachmurove, Department of Economics, The University of Pennsylvania, 3718 Locust Walk, Philadelphia, PA 19104-6297.

This paper has been prepared for the Keynote Speech at the International Conference on "Economic Institutions as a Condition for Social and Economic Development of Transitional Countries,” Kotor, Montenegro, October 2012. I would like to thank the The 
City College of The City University of New York for partial financial support. 


\title{
Failing Institutions Are at the Core of the U.S. Financial Crisis
}

\author{
Dr. Yochanan Shachmurove \\ Department of Economics and Business \\ The City College of the City University of New York, and \\ The Ph.D. Program in Economics, The Graduate School and \\ University Center of The City University of New York
}

\begin{abstract}
This paper uses the structure of institutional economics to provide an explanation of the global financial crisis in the late-2000s. Institutional theory suggests that a county's political, legal, social, and cultural institutions determine and characterize its economy. An institutional perspective of financial crises therefore incorporates unquantifiable aspects of the real world. Different institutions interacted to ignite and fuel the global crisis of the late 2000s. A thorough understanding of all of the legal, political, and cultural institution that encompass a society, as well as their role in the market, is needed to explain and avoid the reoccurrences of financial crises.
\end{abstract}

JEL Classification: G, O1, B52

Key Words: Institutional Economics; Financial Crisis; Law and Economics; Interdependence; Behavioral Economics; Behavioral Finance; Hume; Veblen; Coase 


\section{Failing Institutions Are at the Core of the U.S. Financial Crisis}

\section{Introduction}

Institutional economics has become an increasingly popular topic of research among economists in recent decades. At its heart, institutional economics explains economic trends through the influence of institutions on markets. Institutions are defined as formal and informal rules, regulations, norms, and understandings that both limit and enable behavior (see for example, North, 1974, Campbell, 2004, Scott, 2008, Morgan, Campbell, Crouch, Pedersen and Whitley, 2010).

The theory suggests that a country’s institutions - its political, legal, educational, and social systems - determine and characterize its economy. The philosophy behind this economic school of thought is that, because people interact with institutions on a daily basis, institutional environments shape the way people perceive economic relations. For example, market transactions cannot be made without canonical procedures such as the drawing of contracts, the inspection of products, and so on (Library of Economics).

The incorporation of human psychology, culture, society, and evolution into a theory to describe market activities is rooted in influences from early economic philosophers. In particular, institutional economics has its roots in the economic theories of David Hume (1740). Hume emphasizes the interdependence of economics, law and morality. In contrast to Adam Smith (1776), Hume considers competing interests and aspects of human imperfections. Hume supposes that desire rather than reason and rationality govern human behavior. Institutional economics draws upon Hume’s emphasis on the dependence of the economy on social institutions. Coase (1991) in his Nobel lecture writes: "A principal theme of The Wealth of Nations was that 
government regulation or centralized planning was not necessary to make an economic system function in an orderly way. The economy could be coordinated by a system of prices (the "invisible hand") and, furthermore, with beneficial results" (see, Coase1992).

In comparison to classical economic thought, institutional economics highlights the dependency of the economy on political and social structures. One critique of mainstream economics is that it seldom takes into account features of the real world. Neoclassical economics builds on the assumption that economic decision makers act rationally. A branch of institutional economists called behavioral economics calls into question the reasonableness of this premise. Behavioral economics has played a fundamental role in the innovation of economic institutions, long before behavioral economics was even recognized as a discipline (Shiller, 2005). Behavioral economists argue that human psychology and irrationality greatly influence market patterns. Similar to other branches of institutional economics, behavioral economists argue that the classical understanding of the economy is oversimplified and impractical (see, for example, Simon, 1984, 1985, Akerlof and Shiller, 2009, Shiller 2003, 2005, 2006, 2008, 2009, 2010A, 2010B, 2012, and Shiller and Shiller, 2011).

To understand the modern institutionalist approach to economics, it is useful to consider the foundational underpinnings of these theories. Thorstein Bunde Veblen (1904) is cited as the founding father of institutional economics. Veblen presents a traditional institutionalist critique of classical economics. His theory is based on the idea that people base economic decisions not on purely rational goals, but on desires that are constantly molded by cultural circumstances. The ideas of irrationality and unpredictability of economic actors are conceptual springboards for modern interpretations of economic crises.

John Commons (1921) expands Veblen’s ideas and endorses an interdisciplinary 
approach to economics. In his essay Institutional Economics, Commons argues that the collective action, combined with human self-interest, characterizes economic trends. The key idea is that comprehending collective action is crucial to understanding how individuals behave and contribute to markets under changing social conditions. "Institutional economics," Commons writes, "is not divorced from the classical and psychological schools of economists... But institutional economics is legal control of commodities and labor, where the classical and hedonic theories dealt only with physical control” (Commons, 1921, see also Commons, 1932 and 1950).

Studying economics through the perspective of changing social conditions and evolving institutions is the hallmark of institutional economics. The increasing complexity of modern economies is intertwined with the growing sophistication of manmade institutions. Drawing from the traditions of Commons and Veblen, economist John Galbraith (1979) authored a series of influential and modernized arguments for institutionalism. Galbraith rejects the adherence of classical economics to strict economic laws and assumptions on the grounds that a country's economy is the product of complex social and cultural interactions. Galbraith points to the general neglect by classical economists of cultural and political factors. He mentions examples such as advertising, corporate structure, and government spending. This, he maintains, is a significant shortcoming of the classical school of thought.

Although Galbraith did not live to experience the economic crisis of recent years, his proposals concerning institutionalism are insightful to the modern economic conditions that may have given rise to the almost collapse of market systems around the world. He claims that as a nation emerges from an epoch characterized by poverty into one characterized by affluence, the separation of private and public sectors becomes an 
increasingly salient feature of the economy. While economic prosperity enables more individuals to achieve wealth, national affluence develops at the expense of the public interest. As demand for private goods are driven by the desire for profit, regulation were loosened to give into such demands.

For further developments on the importance of institutions in explaining economic and financial phenomena see the extensive works of North (1974, 1982, 1989A, 1989B, 1990, 1991, 1994, 2005), and of North and his collaborators, i.e., North, Alston and Eggertsson,1996, North, and Davis, 1971, North and Thomas 1976 and North, Wallis, and Weingast, 2009. In a series of works, Williamson (2010, 2009, 2003, 2002, 1996, 2000, 1985) extends the idea of transaction costs advanced by Coase $(1937,1960)$ and relates them to the forms of institutions.

Other works in progress, which are subject to current debates about the effects of institution on the economic development of nations, include the writings of, among others, Acemoglu (2008), and Acemoglu and his collaborators (Acemoglu, Johnson, and Robinson, 2001, 2002; Acemoglu and Robinson, 2008, 2012; Acemoglu, Cantoni, Simon and Robinson, 2009, 2012). However, Sachs (2003, 2006, 2012) maintains that relying only on the institution as the sole driver of economic development is too simplistic of an approach. Ersoy and Shaffranka (2011) analyze the debate between Acemoglu and Sachs on whether institutions are really the ultimate cause of economic failure for nations. See also Polterovich (2008) who studies institutional trap that hindered reforms in transition economies. 


\section{Institutional Explanation of the Financial Crisis}

In recent years, many economists have turned to institutionalist explanations, both traditional and novel, to analyze the factors that caused the global financial crisis in the late-2000s. Though institutional economists present various theories to describe the forces behind the financial meltdown, they generally agree that to fully understand the watershed economic events of recent years is to know the activity of institutions that are integrated with the greater economy. Conventional economic thinking, including the proposal that analysis of risk and other quantitative facets are sufficient methods to study markets, cannot fully explain the financial crisis. This is because conventional economics neglects to incorporate evolving circumstances of the real world, which are unquantifiable.

In order to understand how various institutions interacted first to ignite and then to fuel the global financial crisis, it is important to grasp the role of the financial institution as an underlying cause of the crisis. Beginning around the mid-1900s, economists influenced by the ideas of institutionalism recognized the importance of financial actors in influencing economic trends. Hyman Minsky (1974), a pathfinder on the subject of financial crises and market changes, is one of the first economists to suggest that financial and economic activities have an interdependent relationship. Minsky asserts that financial shifts are not only observable, but also an inevitable feature of a capitalist market. He claims that a fundamental characteristic of the modern economy is that the financial system swings between robustness and fragility. He saw in these swings an integral part of the process that generates business cycles, see for example, Yellen (2009). 
Minsky’s "financial instability hypothesis" attempts to explain market volatility using knowledge of financial trends. The essence of the theory is that economic meltdowns are inevitable in a free economy due to financial shifts. According to the theory, wealth inclines financial actors to engage in more risky behavior, thereby undermining economic stability. Borrowers, lenders, and regulators are all lulled into complacency as asset prices rise. Thus, a sense of safety on the part of investors is characteristic of financial booms, although prices are rising and risk is increasing. The specific stages of the financial cycle in Minsky's theory can be generalized to conservative, risky, and dangerous financial approaches. The theory expands upon behavioral economics, suggesting that economic trends can be explained by the profitseeking drive of economic players (Whalen, 2012).

Features of the financial instability hypothesis were evident in the 1990s tech bubble burst and during the 2000s housing crisis. The advent of the latter is widely considered among economists to be the cause of the financial meltdown. The collapse of the subprime mortgage industry, where banks gave mortgages to individuals who had poor credit, led to dangerous financial speculations. The innovation of asset-backed security allowed borrowers to offload some risk to investment banks. Investment banks, accepted the risks associated with hefty liabilities in order to receive greater profit from mortgage lending.

Minsky's predicted consequence of highly speculative behavior was realized in the brazen actions of institutional investors. In combination with lax governmental financial regulation, poor investment decisions ultimately produced a dangerously volatile economic environment. Driven by the assumption that financial institutions are "too big to fail," institutional investors such as insurance companies, investment portfolios, 
hedge funds and even government organizations all relied on speculative financial products at the dawn of the crisis. The financial crisis could not have gotten its start without the sweeping lack of forethought in the speculations made by institutional investors large and small. Investors willingly purchased risky financial products despite knowing the risks involved with such decisions. The duplicity on the part of banks is a culprit that can be largely ruled out given the banks’ upfront marketing of their services. Institutional investors supplied banks with an alarmingly high demand for risky financial packages.

Without such a demand for these packages, banks would not have been encouraged to readily make available new and ever increasing riskier products. Many of these new, so called, exotic instruments were structured, or better engineered, to obtain high ratings by the rating agencies (see, for example, Benmelech and Dlugosz, 2009, who find that issuers of financial securities were 'shopping' among the rating agencies in order to secure the highest ratings). Lagner and Knyphausen-Aufseb (2012) discuss the role of credit ratings and provide a comprehensive overview of their relevance to key stakeholders ranging from the issuers and investors into bonds, to government institutions and the credit rating agencies themselves.

The failure of institutional investors to consider the inevitably dire consequences of their behavior during profitable times resulted in a mess of finger-pointing once the economic conditions turned for the worse. See, for example, Maconi, Massa and Yusada who hypothesize that investors who interacted with more volatile financial packages experienced greater pressure to sell and higher losses (Maconia, Massa, Yusada; 2010).

As a consequence of their dangerous speculative behavior, financial institutions 
accumulated enormous amounts of debt at the conclusion of the subprime mortgage craze. As housing prices stopped rising, investors began to abandon the mortgage market. A downward spiral ensued - banks tightened credit, accumulated debt, and pushed the national economy to a state of panic.

The profit-seeking drive that is the basis of Minsky's theory on volatility also provides insight as to why, at the time, another well respected institution; namely, the credit rating agencies; failed to reign in risky financing. Thus, in early 2000, Moody's, a longtime private credit rating agency, revealed its decision to become a publicly traded entity. The relationship between credit rating agencies like Moody's and investment banks around that time were complicated by a profit-transformed culture. These agencies were more likely to gain the interests of large banks if they rated them favorably (Selig, 2012). Benmelech and Dlugosz (2009) consider that alarmingly high ratings and erroneous modeling contributed to the failure of rating agencies to prevent the crisis as well as their contribution to its onset (Benmelech and Dlugosz, 2009), see also Blinder (2007).

The institutional pressure toward the financial and economic meltdowns was further bolstered in the late 2000s by failures of various other institutions to respond to the increase in risky behavior by economic actors. The legal system was one of these institutions. Lax legal enforcement of ethical business practices, for example, allowed inaccurate credit ratings to be passed as earnest reports. Consequently, credit rating agencies convicted of colluding with investment banks were able to successfully defend themselves against these allegations by citing first amendment rights (Selig, 2012).

Another system which had one of the greatest impacts by far of institutions on the economic crisis was poor government regulation of the financial industry. In the early 
1900s, strict regulations forced banks to make loans conditional on high investor credit. However, in more recent years, the U.S. government repealed or weakened regulatory acts. Among the weakened laws at fault was the net capital rule, which standardized the amount of debt investment banks were allowed to accrue. Many economists argue that, in relation to the rate at which new financial methods evolved, government regulations of business failed to predict and restrain dangerous financial activities.

The U.S.A.'s lax regulation of the financial sector was further evidenced by federal endorsement and participation in speculative financial behavior. A case in point is The Government National Mortgage Association (also known as Ginny Mae) that gave dubious authorization to various lenders including Lend America. Although Ginny Mae stood behind its decisions during the cusp of the crisis, it became evident that the organization's continued endorsement of the buying and selling of home loans fueled the speculative fervor of the housing crisis (Grow and Goldfarb, 2011). Moreover, Ginny Mae exemplifies the mismanagement of ever increasing risk despite the people's expectation that, in case of a crisis, the U.S. government will, as it actually did, bail the borrowers out and avoids the bankruptcy of Ginny Mae.

In sum, the road to recovery for the U.S. and global economies is determined significantly by the development of appropriate political, legal and cultural institutions. Tighter regulations of financial institutions by themselves are not going to avoid the next economic crisis unless accompanied by a greater understanding of all of the institutions which together encompass a society. 


\section{Conclusion}

The conceptual basis of institutional economics provides a better understanding of financial crises than relying only on classical economics. Underlying the various theories within institutional economics is the idea that economic trends are linked to social, political, and legal institutions. As society becomes more sophisticated, modern economies become increasingly complex. The financial crisis in the late-2000s is characterized by an array of institutional failures. Reckless decisions made by institutional investors, inadequate government regulation of the housing market and nonbank financial intermediaries, and the failure of credit agencies to provide accurate ratings are all institutional factors which have led to the creation of financial turmoil and extended the length of the Great Recession. Groundless optimism and herd behavior on the part of both sides of the transactions encouraged banks to financially engineer risky products, devising new financial instruments and products that very few market players really understood. The failure of credit rating agencies to question and alert the markets to dubious practices supported the trend of reckless investing culminated in the financial system breakdown. Speculative behavior was further propelled by inadequate government regulations and the absence of legal oversight by both the Federal Reserve Bank and other government agencies responsible for monitoring the economy and its financial institution.

A thorough comprehension of financial and regulatory institutions as well as their role in the market would lead to better institutions in the future. 


\section{References}

Acemoglu, Daron. (2008), “Oligarchic versus Democratic Societies,” Journal of the European Economic Association, 6(1): 1-44.

Acemoglu, Daron, Simon Johnson, and James A. Robinson. 2002. "Reversal of Fortune: Geography and Institutions in the Making of the Modern World Income Distribution," Quarterly Journal of Economics, 117(4): 1231-94.

Acemoglu, Daron, Johnson, Simon and Robinson, James A. (2001), "The Colonial Origins of Comparative Development: An Empirical Investigation," The American Economic Review, Vol. 91, No. 5 (Dec., 2001), pp. 1369-1401

Acemoglu, Daron, and Robinson, James A. (2012), Why Nations Fail, The Origins of Power, Prosperity, and Poverty, Crown Publishing Group, a division of Random House, inc., New York.

Acemoglu, Daron, and James A. Robinson, (2008) "Persistence of Power, Elites, and Institutions,” American Economic Review, 98(1): 267-93.

Acemoglu, Daron, Davide Cantoni, Simon Johnson, and James A. Robinson, (2009), "The Consequences of Radical Reform: The French Revolution," National Bureau of Economic Research Working Paper 14831.

Acemoglu, Daron, Davide Cantoni, Simon Johnson, and James Alan Robinson, (2011), "The Consequences of Radical Reform: The French Revolution: Dataset," American Economic Review. http:// www.aeaweb.org/articles.php?doi=10.1257/aer.101.7.3286.

Akerlof, George A. and Shiller, Robert J. (2009), Animal Spirits: How Human Psychology Drives the Economy, and Why It Matters for Global Capitalism, Princeton and Oxford: Princeton University Press.

Arestis, Philip and Alfred Eichner, (1998), "The Post-Keynesian and Institutionalist Theory of Money and Credit,” Journal of Economic Issues. Vol 22, pp. 1003-1021. Web. www.jstor.org/stable/4226066. accessed on 10 June 2012.

Benmelech, Efraim and Dlugosz, Jennifer, (2009), “The Credit Rating Crisis” NBER Working Paper No. w15045, June.

Blinder, Alan, Six Fingers of Blame in the Mortgage Mess, New York Times, 9/30/2007

Campbell, John (2004), Institutional Change and Globalization, Princeton, NJ: Princeton University Press.

Coase, Ronald H. (1992), "The Institutional Structure of Production," American 
Economic Review 82(4): 713-719, reprinted in Nobel Lectures, Economics 1991-1995, Editor Torsten Persson, World Scientific Publishing Co., Singapore, 1997

Coase, Ronald H. (1937), "The Nature of the Firm", Economica 4 (16): 386-405.

Coase, Ronald H. (1960), "The Problem of Social Cost", Journal of Law and Economics 3 (1): 1-44.

Commons, John R. (1932), “The Problem of Correlating Law, Economics, and Ethics,” Wisconsin Law Review, 8: 3-26.

Commons, John R. (1950), The Economics of Collective Action. New York: Macmillan.

Commons, John, R. (1921), “Institutional Economics,” American Economic Review, vol.

21, pp. 648-657.

Elliot, Larry (2009), "It's a funny old game: where is the dream team of economists to tackle the slump?" The Guardian. Gaurdian News and Media Limited. May 31, 2009 access on June 10, 2012 at http://www.guardian.co.uk/business/2009/jun/01/larry-elliottfantasy-economics.

Galbraith, John, K. (1979), “The Valid Image of the Modern Economy, and Power and the Useful Economist," In Annals of an Abiding Liberal. New York: Meridian, 3-19 and 353-371.

Grow, Brian and Goldfarb, Zachary, (2011), “Who’s Behind the Financial Meltdown?” The Center for Public Integrity. August 8, 2011. Access on September 2, 2012 at http://www.publicintegrity.org/accountability/finance/corporate-accountability/whosbehind-financial-meltdown

Hume, David (1740). A Treatise of Human Nature (1967, edition), Oxford University Press, Oxford.

Lagner, Thomas and Knyphausen-Aufseb, Dodu Zu (2012), "Rating Agencies as Gatekeepers to the Capital Market: Practical Implications of 40 Years of Research," Financial Markets, Institutions and Instruments, Volume 21, Issue 3, pp. 157-202, August.

Manconi, Alberto; Massa, Massimo and Yasuda, Ayako, (2010), “The Behavior of Intoxicated Investors: The role of institutional investors in propagating the crisis of 2007-2008,” National Bureau of Economic Research, Cambridge: NBER Working Paper 16191, July.

Minsky, Hyman P. (1974), "The Modeling of Financial Instability: An Introduction," Modeling and Simulation. Proceedings of the Fifth Annual Pittsburgh Conference. 5. 
Morgan, Glenn, Campbell, John L. Crouch, Colin, Pedersen, Ove Kaj and and Whitley, Richard, (2010), (Editors) The Oxford Handbook of Comparative Institutional Analysis, Oxford University P, Oxford and New York.

North, Douglass C. (2005), Understanding the Process of Economic Change, Princeton University Press.

North, Douglass C. (1994), "Economic Performance through Time," American Economic Review, 84(3), p p. 359-368. Also published as Nobel Prize Lecture.

North, Douglass C. (1991), “Institutions,” The Journal of Economic Perspectives, 5(1), pp. 97-112.

North, Douglass C. (1990), Institutions, Institutional Change and Economic Performance, Cambridge University Press.

North, Douglass C. (1989), Institutions and economic growth: An historical introduction, Elsevier, 1989.

North, Douglass C. (1989), Constitutions and Commitment: The Evolution of Institutions Governing Public Choice in Seventeenth-Century England, Cambridge University Press.

North, Douglass C. (1982), Structure and Change in Economic History, New York: W. W. Norton and Co.

North, Douglass C. (1974), Growth and Welfare in the American Past, Prentice-Hall.

North, Douglass C., Alston, Lee and Eggertsson, Thrainn (1996), Empirical Studies in Institutional Change, (Editors), Cambridge University Press.

North, Douglass C. and Davis, Lance (1971), Institutional Change and American Economic Growth, Cambridge University Press.

North, Douglass C. and Thomas, Robert P. (1976), The Rise of the Western World: A New Economic History. Cambridge University Press.

North, Douglass C., Wallis, John J. and Weingast, Barry (2009), Violence and Social Orders: A Conceptual Framework for Interpreting Recorded Human History, Cambridge University Press.

"Ronald H. Coase." Library of Economics and Liberty. Web. http://www.econlib.org/library/Enc/bios/Coase.html. accessed on 10 June 2012.

Polterovich, Victor, (2008), "Institutional Trap," The New Palgrave Dictionary of Economics, Second Edition. Eds. Steven N. Durlauf and Lawrence E. Blume, Palgrave 
Macmillan, <http://www.dictionaryofeconomics.com/article?id=pde2008_I000262>

doi:10.1057/9780230226203.0809

Sachs, Jeffrey D. (2012), "Government, Geography, and Growth The True Drivers of Economic Development," September/October, Foreign Affairs.

Sachs, Jeffrey D. (2006), The End of Poverty: Economic Possibilities for Our Time, New York: Penguin.

Sachs, Jeffrey D. (2003), “Institutions Don’t Rule: Direct Effects of geography on Per Capita Income,” NBER Working Paper 9490, February.

Scott, Richard W. (1995), Institutions and Organizations, Third Edition, London, UK: Sage.

Selig, Kevin. “Greed, Negligence, Or System Failure?” The Kenan Institute for Ethics at Duke. www.duke.edu/web/kenanethics/CaseStudies/Moodys.pdf. accessed on 10 June 2012.

Shiller, Robert J. (2012), Finance and the Good Society, Princeton and Oxford: Princeton University Press.

Shiller, Robert J. (2010A), “Crisis and Innovation,” Journal of Portfolio Management, vol. 36, no. 3, Spring, pp. 14-19

Shiller, Robert J. (2010B), "How Should the Financial Crisis Change How We Teach Economics?” Journal of Economic Education, vol. 41, no. 4, pp. 403-09

Shiller, Robert J. (2009), “Unlearned Lessons from the Housing Bubble,” Economists' Voice, vol. 6, no. 7.

Shiller, Robert J. (2008), The Subprime Solution: How Today's Global Financial Crisis Happened, and What to Do about It, Princeton and Oxford: Princeton University Press.

Shiller, Robert J. (2006), Tools for Financial Innovation: Neoclassical versus Behavioral Finance,” Financial Review, vol. 41, no. 1, February, pp. 1-8.

Shiller, Robert J. (2005), “Behavioral Economics and Institutional Innovation,” Southern Economic Journal, vol. 72, no. 2, October, pp. 269-83.

Shiller, Robert J. (2003), The New Financial Order: Risk in the Twenty-First Century, Princeton and Oxford: Princeton University Press.

Shiller, Robert J. (2002), “The Irrationality of Markets,” Journal of Psychology and Financial Markets, vol. 3, no. 2, pp. 87-93. 
Shiller, Robert J. and Shiller, Virginia M. (2011) “Economists as Worldly Philosophers,” American Economic Review, vol. 101, no. 3, May 2011, pp. 171-75

Simon, Herbert A. (1984) "On the Behavioral and Rational Foundations of Economic Dynamics.” Journal of Economic Behavior and Organization, 5(1): 35-55.

Simon, Herbert A. (1985) "Human Nature in Politics: The Dialogue of Psychology with Political Science.” American Political Science Review, 79(2): 293-304

Smith, Adam (1977) [1776], An Inquiry into the Nature and Causes of the Wealth of Nations, University Of Chicago Press.

Veblen, Thorstein (1904), The Theory of Business Enterprise, New York, NY: New American library, Mentor Books.

Whalen, Charles (2012), "Post-Keynesian Institutionalism after the Great Recession," Levy Economics Institute of Bard College, Working Paper No. 724, pp.1-24, May. Web. http://www.levyinstitute.org/pubs/wp_724.pdf. 10 June 2012.

Williamson, Oliver E. (2010), “Transaction Cost Economics: The Natural Progression,” American Economic Review 100, June: 673-690.

Williamson, Oliver E. (2009), “Opening the Black Box of Firm and Market Organization: Antitrust,” In The Modern Firm, Corporate Governance and Investment, ed. Per-Olof Bjuggren and Dennis C. Mueller, 11-42. Northampton, MA: Edward Elgar.

Williamson, Oliver E. (2003), "Examining Economic Organization through the Lens of Contract,” Industrial and Corporate Change, 12(4): 917-42.

Williamson, Oliver E. (2002), "The Theory of the Firm as Governance Structure: From Choice to Contract,” Journal of Economic Perspectives, 16(3): 171-95.

Williamson, Oliver E. (2000), “The New Institutional Economics: Taking Stock, Looking Ahead,” Journal of Economic Literature, 38(3): 595-613.

Williamson, Oliver E. (1996), The Mechanisms of Governance, Oxford: Oxford University Press.

Williamson, Oliver E. (1985), The Economic Institutions of Capitalism, New York: Free Press.

Yellen, Janet L. (2009), “A Minsky Meltdown: Lessons for Central Bankers,” Federal Reserve Bank of San Francisco, April 16, Access at http://www.frbsf.org/news/speeches/2009/0416.html on September 3, 2012. 